\title{
THE
}

\section{Present bias and financial behavior}

Jing Jian Xiao

University of Rhode Island, jjxiao@uri.edu

Nilton Porto

University of Rhode Island, nilton_porto@uri.edu

Follow this and additional works at: https://digitalcommons.uri.edu/hdf_facpubs

The University of Rhode Island Faculty have made this article openly available.

Please let us know how Open Access to this research benefits you.

This is a pre-publication author manuscript of the final, published article.

Terms of Use

This article is made available under the terms and conditions applicable towards Open Access

Policy Articles, as set forth in our Terms of Use.

Citation/Publisher Attribution

Xiao, JJ, Porto, N. Present bias and financial behavior. Financial Planning Review. 2019; 2:e1048.

https://doi.org/10.1002/cfp2.1048

Available at: https://doi.org/10.1002/cfp2.1048

This Article is brought to you for free and open access by the Human Development and Family Science at DigitalCommons@URI. It has been accepted for inclusion in Human Development and Family Science Faculty Publications by an authorized administrator of DigitalCommons@URI. For more information, please contact digitalcommons-group@uri.edu. 
Xiao, J. J., \& Porto, N. (2019). Present bias and financial behavior. Financial Planning Review, 2(2), e1048.

\title{
Present Bias and Financial Behavior
}

\begin{abstract}
Present bias is an important term in the theory of self-control in behavioral finance. Empirical research finds that present bias is associated with undesirable spending, borrowing, and saving behaviors. Unlike previous research that focuses on one domain of financial behavior, the purpose of this study is to examine associations between present bias and a set of financial behaviors in various domains: spending, borrowing, saving, and money management. With data from a national urban sample in China, results show that some behavioral patterns are consistent with theoretical predictions that present biased consumers are more likely to spend in the present and less likely to save for the future. The findings have implications for further research on present bias and help researchers better understand this important concept. The results are also informative for financial planners to better serve their clients.
\end{abstract}

Key words: present bias, self-control, behavioral finance, financial behavior

JEL code: D12, D14

\section{Introduction}

Present bias, the tendency of people to discount their future preferences in favor of more immediate gratification, is an important concept derived from the theory of self-control in behavioral finance (Thaler \& Shefrin, 1981). This concept draws on both theoretical and empirical research. Since present bias involves trade-offs between one's present and future self, the concept has several important ramifications in behavioral finance where rewards are not always immediate and future 
benefits are somewhat uncertain (O'Donoghue \& Rabin, 2015). Present bias is often examined when modeling economic consumer behavior and is considered a trait in economic research. Additionally, it is incorporated in the behavioral lifecycle hypothesis (Shefrin \& Thaler, 1988) and hyperbolic model of consumption and saving (Laibson, 1997).

Previous empirical research has examined potential effects of present bias on financial and other consumer behaviors. Research shows that present biased consumers may spend too much (Nguyen, 2016), borrow too much (Meier \& Sprenger, 2010), and save less (Brown \& Previtero, 2014), compared to other consumers. Present biased consumers also exhibit fewer beneficial health behaviors (Mørkbak, Gyrd-Hansen, \& Kjær, 2017).

A better understanding of the relationship between present bias and financial behavior has practical applications for financial planners. Existent research suggests that present biased consumers tend to perform fewer desirable financial behaviors including a preference for spending today versus saving for the future. If these behaviors are confirmed by empirical studies, the findings are informative for financial planners when they recruit, work with, and retain clients by using different strategies for present biased or other consumers.

Unlike previous research that focuses on a specific behavior or a specific domain of financial behaviors, this study examines associations between present bias and a comprehensive set of financial behaviors regarding spending, borrowing, saving, and money management. Another unique feature of this study is that it uses a direct measure of present bias instead of one derived from a series of questions based on the standard utility function from previous research (e.g. Meier \& Sprenger, 2010). The results suggest that many behavioral patterns are consistent with theoretical predictions. The findings offer insights for further understanding the concept of present bias in research and are 
informative for financial planners when they assist their clients to make effective financial decisions and improve their financial wellbeing.

\section{Conceptual Framework and Hypotheses}

Present bias is a concept from the theory of self-control (Thaler \& Shefrin, 1981). In this theory, the concept of self-control is incorporated in a theory of individual intertemporal choice by modeling the individual as an organization. The individual at a point in time is assumed to be both a farsighted planner and a myopic doer. Later, the concept of dual personality in which a person is both a planner and doer is used by researchers to build their lifecycle consumption theories (Angeletos, Laibson, Repetto, Tobacman, \& Weinberg, 2001; Laibson, 1997; Shefrin \& Thaler, 1988). For example, in the hyperbolic model of consumption (Angeletos et al., 2001; Laibson, 1997), a person is assumed to have dual personalities: a doer and a planner. The doer is a typical present biased person who is not patient and prefers spending to saving, while a planner is patient and willing to forgo some current gratification for future returns. The hyperbolic model uses the standard utility function and integrates advances in psychology such as the concept of self-control to model consumer behavior and derive a quasihyperbolic function. Simulation results show that predictions of this model more accurately describe consumer behavior compared to the exponential model that uses the traditional exponential function to represent the time discounting preference (Angeletos et al., 2001).

Present bias is an element of the realm of self-control (Thaler \& Shefrin, 1981), which resulted originally from animal research in the 1960s-70s (O'Donoghue \& Rabin, 2015). Later, economists adopted the concept and used it in economic research, especially when Laibson used present bias in his dissertation and several following publications (Angeletos et al., 2001; Laibson, 1994, 1997). In this study, present bias is defined as a trait of pursuing instant gratification by overvaluing present rewards at the expense of future returns. In terms of current and future consumption, present biased consumers 
are more likely to spend and less likely to save and invest. Since debts are usually used to finance current consumption, present biased consumers are more likely to borrow (Meier \& Sprenger, 2010). If present biased consumers care more about current consumption and instant gratification, they may display less careful money management behavior. Some evidence shows that present biased consumers may have poorer health (Mørkbak et al., 2017), which may influence their executive function in money management.

How people process, perceive, and react to time has been an important research question in multiple fields of inquiry. In psychology, Zimbardo and Boyd (1999) first coined the term time perspective to describe how holding a past, present, or future attitude affects people's decision making in a number of situations. Time preferences or intertemporal choice have been used in both neoclassical and behavioral economics to validate how people value their present and future selves differently (Frederick, Loewenstein, \& O'Donoghue, 2002). For instance, variations on retirement and savings rates have been explained by how different languages grammatically characterize the gap between present and future self (Chen, 2013). Regardless of the research discipline, people appear to be time inconsistent and easily biased by psychological, structural, or context-specific factors. While the topic is multidisciplinary, the current study focuses on time from a behavioral finance perspective.

Since present bias stems from lower self-control and the desire for immediate gratification, sophisticated versus naïve consumers exhibit distinctive time inconsistencies. Specifically, naifs are unaware of their failings and will seek immediate gratification for things they like but will procrastinate on tasks and choices they feel unpleasant. Consumers who are sophisticated should show a pattern of trying to avoid indulgences by seeking mechanisms to improve self-control (O'Donoghue \& Rabin, 2000).

Previous empirical research examined potential effects of present bias on consumer and financial behaviors that are consistent with the above conceptual discussion. Specifically, present bias 
may influence spending behavior. For example, tourists with high loss aversion and high present bias are more likely to overspend (Nguyen, 2016). Conversely, individuals who are more patient and less presentbiased are known to be more likely to purchase certain energy-efficient appliances (Fuerst \& Singh, 2018).

Present bias may also impact borrowing behavior. For example, people with a present bias are more likely to borrow from credit cards and borrow more from credit cards compared to those who are not present biased (Meier \& Sprenger, 2010). Similarly, present biased consumers are more likely to use complex mortgage products with back-loaded payments, known as "Alternative Mortgage Products" (AMPs), or "Interest-Only Mortgages" (Gathergood \& Weber, 2015). Consumers who exhibit lack of selfcontrol make greater use of high-cost credit items such as store cards and payday loans (Gathergood, 2012). Low self-control has also been linked to greater use of revolving credit (Wang, Lu \& Malhotra, 2011), while chronic debtors - those that consistently spend more than they earn-tend to be more present-oriented (Webley \& Nyhus, 2001).

In addition, present biased people may be reluctant to save. Saving for a long-term goal involves risk. Risk tolerance is an important factor in consumer saving and investing behavior (Grable, 2016). In the United States, because of the unsustainable social security system and the trends away from defined benefit pensions to defined contribution retirement plans that require more individual responsibility for retirement security (Hanna et al, 2016), consumers are expected to participate in and contribute to their retirement accounts that also demand management of these accounts. However, present biased consumers are less likely to engage in desirable retirement saving behavior (Brown \& Previtero, 2014). Amongst other factors such as inertia, present bias is one of the hurdles the Save More Tomorrow ${ }^{\mathrm{TM}}$ program has aimed to overcome to improve workers' retirement savings (Thaler \& Benartzi, 2004). 
Importantly, impatient consumers-relative to those with stronger planner preferences-have fewer liquid savings and lower financial wellbeing (Middlewood, Chin, Johnson, \& Knoll, 2018).

Empirical research on the association between present bias and money management is limited. Some research shows that consumer budgeting and planning behaviors are associated with consumer resource levels, in which consumers with limited resources are more likely to perform budgeting behavior and less likely to engage in planning behavior (Xiao \& O’Neill, 2018a, 2018b). In addition, research has found normative financial management behaviors including calculating retirement needs are positively related to financial resilience when consumers face financial distress (Bhargava, Palmer, Chatterjee, \& Stebbins, 2018). Given that such research suggests an association between present bias and money management exists, future research is warranted.

In summary, based on the conceptual discussion and previous empirical research, present biased consumers are known to exhibit a high discount rate, emphasize current consumption, borrow too much, not care about the future, and not to save enough. In addition, previous research suggests present biased people focus on instant gratification and may not be cautious performing daily money management tasks. Based on these assumptions, we propose following hypotheses:

H1: Present biased consumers are more likely than other consumers to spend.

H2: Present biased consumers are more likely than other consumers to borrow.

H3: Present biased consumers are less likely than other consumers to save.

H4: Present biased consumers are less likely to engaging in money management behavior.

\section{Methods}

Data 
Data for this study came from the 2014 China Survey of Consumer Finances (CSCF), a national survey on urban households, designed by consumer finance researchers at Tsinghua University. The nationally representative sample contains information on 3,921 households from 25 provinces or municipalities. Populations in these provinces/municipalities constitute $95 \%$ of the national population. The survey collects household finance data through a computer-assisted-personal-interview, generally lasting 30 minutes. CSCF shared samples with the China Family Panel Studies (CFPS), administrated by researchers at Peking University in China (Liao, Xiao, Zhang, \& Zhou, 2017; Xie \& Hu, 2014). After removing observations with missing values of key variables, the final sample size used in the analyses was 3,843 .

\section{Variables}

\section{(Insert Table 1 about here)}

Table 1 presents variable specifications. The variable of present bias was measured by the question "I intend to live in the present more and do not consider the future". Participants responded on a 1-5 scale where 1-Totally inapplicable, 2-Somewhat inapplicable, 3-Generally applicable, 4Somewhat applicable, and 5-Totally applicable. The higher the score, the higher the level of present bias.

Fifteen broadly defined financial behavior variables were identified and included in this study. These variables were divided into four categories: spending, borrowing, saving, and money management. The four spending behaviors were underspending, considering if affordable when shopping, preferring spending over saving, and willingness to spend money now. The two borrowing behaviors were maintaining balance for loans and willingness to borrow more. Four behaviors were related to saving and investing. One saving behavior was calculating retirement needs. One variable was about risk aversion that was considered an investing behavior. Two variables were about willingness to 
take high return (50\%) investment opportunities introduced by ads and willingness to take high return $(50 \%)$ investment opportunities introduced by friends. Note that these behaviors were used nominally as indicators of investing behavior. Since the $50 \%$ return rate was nearly impossible to obtain in the investment markets at the time of survey, it is important to note that these questions may be measuring consumer naiveté in relation to the investment market. In the initial conceptual discussion, we included these two behaviors in the domain of saving behavior based on their nominal contents, but later we found they belong to a different, new category (see the result section for more details). Five variables asked about money management behavior: paying bills on time; making long term plans; keeping track of financial records; searching for information and comparison shopping; and having a habit of bookkeeping.

Most behavior variables were measured by a 5-point scale. For example, the variable of considering if affordable when shopping was measured by asking, "I will consider my capacity when I go shopping: 1-Totally inapplicable, 2-Somewhat inapplicable, 3-Generally applicable, 4-Somewhat applicable, 5-Totally applicable, 9-Don't know". Respondents who answered 9 were coded as "totally inapplicable." Four variables were measured in different scales. Calculating retirement needs was measured with the variable, "Whether you and your spouse have calculated the amount of money to cover your elderly life cost?", 1-Yes, 5-No. In the data analyses, the variable was recoded to 1-No and 5Yes. Risk aversion was measured as "If your family invests/In investment, what kind of risk are you willing to take?", 1-High risk, high return; 2-Moderate risk, steady return; 3-Low risk, low return; 4Unwilling to take any investment risk. This variable was recoded as 1.25 -unwilling to take any investment risk, 2.5-low risk, low return, 3.75-moderate risk, steady return, and 5-high risk, high return. The two investment opportunity variables were measured by questions with three options. For example, one question was "If an advertisement claims that there is an investment project with an annual return rate at 50\%, would you invest in it?" 1-Yes, 2-No, 3-Will decide after learning more details of the project. 
In the data analyses, in order to let a higher value represent a higher likelihood, the values were recoded as: 1.-No, 3-Will decide after learning more details, and 5-Yes.

Following previous research (e.g., Meier \& Sprenger, 2010), several control variables were used in the analyses, including gender, age, ethnicity, personal income, marital status, and education. Gender was measured as 0-female, 1-male; ethnicity was measured as 0 - minority, 1 -Han (most Chinese belong to this ethnicity). Age was the actual year and personal income was monthly income in RMB (Chinese yuan). Education had the following five categories: primary school or lower, middle school, high school, three-year college (equivalent to an associate degree in the US), and college degree or higher, and were measured with binary variables.

\section{Analyses}

To reduce the variable number and explore meanings of financial behaviors, 15 financial behavior variables were used in an exploratory factor analysis. Variables in each dimension identified in the factor analyses were averaged to formulate the composite financial behavior variables. This was followed by a series of OLS regressions. The regressions were conducted to explore associations of present bias variables and financial behaviors without or with control variables. For each behavior variable, three models were used. In model 1 , only the present bias variable was used as the independent variable. In model 2 , the present bias squared term was added to detect if there was any nonlinear pattern. In model 3, the demographic variables were added as controls to examine if the present bias variables still displayed associations when these control variables were added. The models can be expressed as:

(1) $F B=a+b * P B+\varepsilon$

(2) $F B=a+b^{*} P B+c^{*} P B^{2}+\varepsilon$

(3) $F B=a+b * P B+c^{*} P B^{2}+D^{*} X+\varepsilon$ 
Where, $\mathrm{FB}=$ financial behavior, $\mathrm{PB}=$ present bias, $\mathrm{PB}^{2}=$ present bias squared, $\mathrm{X}=$ a vector of control variables, $\varepsilon=$ error term; $a, b, c, D$ are coefficients to be estimated. The maximum or minimum value of PB could be calculated after the coefficients are estimated. For example, for model 3, the following formula was estimated:

(4) Max or Min of FB = -b/2c.

\section{Results}

Descriptive Statistics of the Sample

(Insert Table 2 about here)

Table 2 presents descriptive statistics of the sample. For the present bias variable, the score was 2.77 out of 5 . Fifteen financial behaviors showed three patterns, the lower end (1-2), middle range (2.12.99), and higher end (3-5). Four behaviors were in the lower end: take high return investment opportunity introduced by ads, take high return investment opportunity introduced by friends, willing to take more debts, and maintain balance in loans. Seven behaviors were in the middle range. These behaviors included: calculate retirement needs, have a habit of bookkeeping, willing to take financial risk, make long term financial plans, prefer spending over saving, willing to spend money now, and collect information and compare products. Four financial behaviors were in the higher end: pay close attention to own financial situation, consider if affordable when shopping, consume according to own income, and pay bills on time.

Among the sample, $94 \%$ were Han, the average age was 55 years, $52 \%$ were male and $80 \%$ were married. The average personal monthly income was RMB14,720. For education levels, $25 \%$ had a primary school or lower education, $28 \%$ middle school, $25 \%$ high school, $11 \% 3$-year college, and $11 \%$ a college degree or more education. 
Results of Exploratory Factor Analysis

(Insert Table 3 about here)

Table 3 shows results of the exploratory factor analysis on the 15 financial behaviors. Five factors emerged. The first three behaviors (items 1-3 in Table 3), paying bills on time, considering if affordable when shopping, and underspending, loaded onto Factor 1 . These were related to spending behavior, especially emphasizing cautious spending. We then labeled this behavior as "cautious behavior". The next three behaviors (items 4-6) were: having long term plans, bookkeeping, and searching for information. These behaviors were related to money management and labeled "managing behavior." The seventh item, checking finance, had large loadings on both factor 1 and 2 . Due to its unclear interpretation, this variable was removed from later analyses. The eighth item, keeping loan balances, had a comparatively lower loading score compared to other variables on this factor and was not considered in later analyses for two reasons: its loading value was low (less than .5), and it was unclear how to interpret its relevance to other behaviors in this factor.

Items nine and ten loaded together closely. These items implied that consumers would like to take extremely high return (50\%) investment opportunities introduced by ads or friends, and were therefore labeled "naïve behavior" since no such returns exist in the market. In this factor, item 11 also had a high loading. Since it was incompatible with the other items and hard to interpret, the item was removed from later analyses. Items $12-13$ loaded on the fourth factor, which was related to the preference for current spending to saving, then labeled "impatient behavior." Items 14-15, calculating retirement needs and not willing to borrow more (since it is negatively loaded), implied the tendency to analytically consider retirement needs and debt burden, which was then labeled "analytic behavior."

For each factor, five composite financial behavior variables were created by averaging scores of the variables identified in each factor as follows: cautious, managing, naïve, impatient, and analytic 
behavior. These behaviors represent those defined from various domains, such as spending, borrowing, saving, and money management, but also have some differences. In cautious behavior, among the three items, one is about money management and two about spending. In managing behavior, all four items belong to money management. In impatient behavior, two items belong to spending. In naïve behavior, two items can be considered as naïve investing behavior. In analytic behavior, one item belongs to retirement saving and the other is about borrowing, or not borrowing when it was reverse coded to form the composite behavior variable.

Figures Showing Associations between Financial Behaviors by Present Bias Status

(Insert Figure 1 about here)

As preliminary analyses, we created five figures showing possible associations between present bias and financial behaviors (Figure 1). Cautious behavior showed a U-shape among present bias scoring from low to high. Analytic behavior also showed a U-shape with present bias scores, which ranged from low to high. Managing behavior was negatively associated with present bias. Impatient behavior was positively associated with present bias, suggesting present biased consumers prefer spending to saving. Naïve behavior showed a negative association with present bias, implying more present biased persons may be less likely to engage in this behavior. If naïve behavior is in the domain of saving/investing, the pattern is consistent with $\mathrm{H} 3$. If impatient behavior is in the domain of spending, the pattern is consistent with $\mathrm{H} 1$. Most items in cautious behavior belong to spending behavior and the pattern is only partially consistent with $\mathrm{H} 1$. If analytic behavior is considered in the domain of saving/investing, the pattern is only partially consistent with H3. All items in managing behavior are about money management and the pattern is consistent with $\mathrm{H} 4$. No behavior is clearly in the domain of borrowing, therefore, $\mathrm{H} 2$ cannot be verified.

Results of OLS Regressions on Financial Behaviors 
(Insert Table 4 about here)

In this paper, the conventional 5\% significance level was used when reporting results. Table 4 shows the regression results on cautious behavior. In model 1, only the present bias variable was included, which showed a positive association. In model 2, the present bias squared term was added, the coefficient estimate of present bias showed a negative sign and the present bias squared term showed a positive sign, indicating a U-shape association. In model 3, several control variables were included and the coefficient estimates of the two present bias variables increased and remained significant, keeping the U-shape association. Based on the results of model 3, present bias was negatively associated while the present bias squared term was positively associated with this behavior, which confirmed the result of the bivariate graphing analysis, showing a U-shape between present bias and cautious behavior. Comparing the betas (standardized coefficients) between present bias variables and the control variables, those of present bias variables were much larger than the control variables, implying the present bias variables were more closely associated with this behavior than control variables. We also calculated the value of present bias when cautious behavior reached the minimum value (the answer was 2.6), which implied that before the present bias value reached 2.6, its association with cautious behavior was negative, which partially supports H1. In addition, females or those who were married were more likely to exhibit this behavior. Compared to those with no or only primary school education, those with middle school or higher education levels were more likely to perform this behavior.

(Insert Table 5 about here)

Table 5 presents regression results on managing behavior. In model 1, the present bias variable was negatively associated with managing behavior. In model 2 , both the present bias variable and its squared term had negative coefficient estimates, but both were not significant. In model 3, after the 
control variables were added, both present bias variables still showed insignificant associations. The results suggest that present bias variables were not associated with managing behavior, which is inconsistent with $\mathrm{H} 4$. Since the squared term's coefficient was much smaller than that of the present bias variable, and the value of present bias variable that reached the minimum value of managing behavior is 30.3 (out of the range of possible values for the present bias variable), present bias was found to be negatively associated with managing behavior, although the association was statistically insignificant. In addition, based on results from model 3, several demographic variables were found to be associated with managing behavior. Those who were younger, married, and had higher income or higher education levels were more likely to exhibit managing behavior.

\section{(Insert Table 6 about here)}

Table 6 indicates regression results on impatient behavior. In model 1, the present bias variable showed a positive association. In model 2 , when the present bias squared term was added, a positive association with a decreasing rate was shown. In model 3, when control variables were entered, the same patterns of present bias variables were still shown. The value of present bias was 7.4 when impatient behavior reached the maximum value, which was greater than 5 , implying that present bias was positively associated with impatient behavior with a decreasing rate within the range of 1-5. Also, no control variables showed significant associations with impatient behavior, implying that only present bias was closely associated with impatient behavior.

\section{(Insert Table 7 about here)}

Table 7 reports regression results on naïve behavior. The result of model 1 showed a negative association, while in model 2, the two coefficients of present bias showed an inverse U-shape association with this behavior. In model 3, when control variables were entered, the coefficient estimate of present bias became insignificant $(p=.067)$ and that of its squared term was significant, still showing 
an inverse U-shaped association. As the value of present bias reached 2.1, the naïve behavior reached the maximum value. This implied that after present bias's value reached 2.1 , it started to be negatively associated with naïve behavior (considered as an investing behavior), which was partially consistent with H3. In addition, minorities, younger people, and those with primary school or lower education (compared to those with middle school education) were more likely to exhibit this behavior.

\section{(Insert Table 1 about here)}

Table 8 presents regression results on analytic behavior. In model 3, present bias variables showed a U-shaped association with this behavior, in which present bias was negatively and present bias squared was positively associated with this behavior. The present bias value was 3.5 when analytic behavior reached the minimum value, implying that before the present bias score reached 3.5, it would be negatively associated with analytic behavior (considered as a saving behavior), which was partially consistent with H3. In addition, the Han ethnicity or older were positively associated with this behavior.

\section{Conclusions, Limitations, and Implications}

This study examined associations between present bias and a set of financial behaviors in various domains. With data from a national urban sample in China, the results are consistent with some theoretical predictions about present bias, such as preferring current spending and postponing saving. Results revealed five composite behaviors, including a unique behavior labeled "naïve behavior."

Based on the exploratory factor analyses, fifteen individual financial behaviors were categorized to five composite behaviors: cautious, managing, impatient, naïve, and analytic behaviors. Most redefined behaviors are consistent with previously defined financial behaviors. For example, cautious and impatient behavior are similar with spending behavior, managing behaviors are close to money management behavior, and analytic behavior is similar with saving behavior. But one redefined behavior, naïve behavior, is not in the scope of early defined financial behavior. This behavior is a 
nominal saving behavior but may also be an indicator of consumer vulnerability, an innovative finding of this study.

Multivariate OLS regression results on composite financial behaviors, after controlling for demographic variables, showed that present bias was positively associated with impatient behavior but not associated with managing behavior. In addition, present bias showed a U-shape association with cautious behavior and analytic behavior, while a reverse U-shape association with naïve behavior. These findings partially support theoretical predictions. Based on the theory of self-control (Shefrin \& Thaler, 1988; Thaler \& Shefrin, 1981) or hyperbolic model of consumption (Angeletos et al., 2001; Laibson, 1997), present biased consumers should prefer spending to saving, which is supported by some findings of this study, in which present bias is positively associated with impatient behavior.

However, several U-shape or inverse U-shape associations were found pointing to a more ambiguous relationship between the presence of present bias and consumer financial behaviors. For example, present bias showed a U-shape association with cautious behavior, a behavior emphasizing cautious spending, which should be negatively associated with present bias. A U-shape association suggests the finding supports the theoretical prediction partially. The same situation applies to the findings of analytical behavior. For the naïve behavior, a present bias value of less than 2.1 is problematic while values above 2.1 seem to protect consumer from investing in unrealistic and potentially fraudulent investments. A potential explanation is that being "too" present-biased will lead some consumers to ignore "too good to be true" opportunities. It follows that future-oriented consumers might be more likely to seek large gambles to improve their future, similar to the FriedmanSavage model (1948).

Findings from this study suggest that financial behaviors may be categorized in different ways, based on statistical analyses and behavior performance patterns instead of traditional domains such as 
spending, borrowing, saving, and money management. Overall, based on this Chinese dataset, five behaviors emerged, including a new behavior-naïve behavior-adding to the literature. Naïve behavior was not defined in the conceptual discussion before data analyses were conducted.

Limitations of this study need to be acknowledged. First, the behaviors examined in this study were self-reported. Information taken from actual observed behaviors, such as administrative data, would further strength this line of research. Second, an independent borrowing behavior is absent from the factor analyses, in which original individual behaviors were either not used or combined with other composite behaviors. In future research, data sets with more borrowing questions could be used to verify the association between present bias and borrowing behavior. Third, this study used data from only one country, China, and only urban households were included in the survey. It is important to point out that Chinese households have higher rates of savings than those in most Western countries. Future research should use data from more countries to examine similarities and differences of possible effects of present bias on financial behaviors across countries.

Results of this study have implications for helping consumers avoid present bias and make effective financial decisions. Present bias matters in behavioral finance. De-biasing mechanisms have the potential to help consumers overcome present bias and reach better financial choices. Nudges, commitment devices, and methods to scaffold one's future self can provide valuable improvements to the discounting factor or even overtake it entirely (Thaler \& Sunstein, 2009). Those involved in the delivery of financial education can play an important role in the process of weakening the negative consequences of present bias by sharing not just relevant knowledge but also financial tools and techniques to help the de-biasing process.

Findings of this study have several implications for financial planners who play an important role in advancing consumer financial wellbeing. Financial planners may be able to identify present 
biased clients by asking questions similar to the ones employed in this study regarding their present vs. future orientation or spending vs. saving preferences. Next, clients identified as present-biased may be offered additional support such as auto-enrollment programs to foster better financial habits such as default strategies to develop an auto savings plan (Middlewood et al., 2018). Financial planners may also utilize some of the strategies suggested in the book "Nudge" (Thaler \& Sunstein, 2009) to help present biased clients to moderate their tendency of emphasizing present consumption. These strategies can be summarized as NUDGES (iNcentives, Understanding mapping, Defaults, Give feedback, Expect error, and Structure complex choices).

Further, financial planners may need to be more patient and methodical when preparing longterm financial planning to clients who display present bias. While the present biased client might sacrifice saving for the future in the name of immediate gratification, this study also reveals that present biased consumers are less likely to perform naïve investing behavior. Financial planners have the difficult task to similarly identify future-oriented clients to educate them about the risks associated with investing on extremely high return investment opportunities. These types of investment are not beneficial investing behavior but potential self-destroying behavior. 


\section{References}

Angeletos, G. M., Laibson, D., Repetto, A., Tobacman, J., \& Weinberg, S. (2001). The hyperbolic consumption model: Calibration, simulation, and empirical evaluation. Journal of Economic Perspectives, 15(3), 47-68.

Bhargava, V., Palmer, L., Chatterjee, S., \& Stebbins, R. (2018). Supportive and mitigating factors associated with financial resiliency and distress. Financial Planning Review, 1(3-4). https://doi.org/10.1002/cfp2.1023

Brown, J. R., \& Previtero, A. (2014). Procrastination, present-biased preferences, and financial behaviors. Landscape Research Japan Online, 65, 543-546.

Chen, M. K. (2013). The effect of language on economic behavior: Evidence from savings rates, health behaviors, and retirement assets. American Economic Review, 103(2), 690-731.

Frederick, S., Loewenstein, G., \& O'Donoghue, T. (2002). Time discounting and time preference: A critical review. Journal of Economic Literature, 40(2), 351-401.

Friedman, M., \& Savage, L. J. (1948). The utility analysis of choices involving risk. Journal of Political Economy, 56(4), 279-304.

Fuerst, F., \& Singh, R. (2018). How present bias forestalls energy efficiency upgrades: A study of household appliance purchases in India. Journal of Cleaner Production, 186, 558-569.

Gathergood, J. (2012). Self-control, financial literacy and consumer over indebtedness. Journal Economic Psychology, 33(3), 590-602.

Gathergood, J., \& Weber, J. (2015). Financial literacy, present bias and alternative mortgage products. Journal of Banking \& Finance, 78, 58-83.

Grable, J. E. (2016). Financial risk tolerance. In J. J. Xiao (ed.). Handbook of consumer finance research ( $2^{\text {nd }}$ ed.). New York: Springer. 
Hanna, S. D., Kim, K. T., \& Chen, S. C. (2016). Chapter 3: Retirement savings. In J. J. Xiao (ed.). Handbook of consumer finance research. New York: Springer.

Laibson, D. I. (1994). Hyperbolic discounting and consumption (Doctoral dissertation, Massachusetts Institute of Technology).

Laibson, D. (1997). Golden eggs and hyperbolic discounting. Quarterly Journal of Economics, 112(2), 443477.

Liao, L., Xiao, J. J., Zhang, W., \& Zhou, C. (2017). Financial literacy and risky asset holdings: Evidence from China. Accounting and Finance, 57, 1383-1415.

Meier, S., \& Sprenger, C. (2010). Present-biased preferences and credit card borrowing. American Economic Journal: Applied Economics, 2(1), 193-210.

Middlewood, B. L., Chin, A., Johnson, H., \& Knoll, M. A. (2018). Exploring the relationships between impatience, savings automation, and financial welfare. Financial Planning Review, 1(3-4). https://doi.org/10.1002/cfp2.1020

Mørkbak, M. R., Gyrd-Hansen, D., \& Kjær, T. (2017). Can present biasedness explain early onset of diabetes and subsequent disease progression? Exploring causal inference by linking survey and register data. Social Science \& Medicine, 186, 34-42.

Nguyen, Q. (2016). Linking loss aversion and present bias with overspending behavior of tourists: insights from a lab-in-the-field experiment. Tourism Management, 54(36), 152-159.

O'Donoghue, T., \& Rabin, M. (2000). The economics of immediate gratification. Journal of Behavioral Decision Making, 13(2), 233-250.

O'Donoghue, T., \& Rabin, M. (2015). Present bias: Lessons learned and to be learned. American Economic Review, 105(5), 273-279.

Shefrin, H. M., \& Thaler, R. H. (1988). The behavioral life-cycle hypothesis. Economic Inquiry, 26, 609643. 
Thaler, R. H., \& Shefrin, H. M. (1981). An economic theory of self-control. Journal of Political Economy, 89(2), 392-406.

Thaler, R. H., \& Benartzi, S. (2004). Save more tomorrow ${ }^{\mathrm{TM}}$ : Using behavioral economics to increase employee saving. Journal of Political Economy, 112(S1), S164-S187.

Thaler, R. H., \& Sunstein, C. R. (2009). Nudge: Improving decisions about health, wealth, and happiness. New York, NY: Penguin.

Wang, L., Lu, W., \& Malhotra, N. K. (2011). Demographics, attitude, personality and credit card features correlate with credit card debt: A view from China. Journal of Economic Psychology, 32(1), 179193.

Webley, P., \& Nyhus, E. K. (2001). Life-cycle and dispositional routes into problem debt. British Journal of Psychology, 92(3), 423-446.

Xiao, J. J., \& O’Neill, B. (2018a). Mental accounting and behavioral hierarchy: Understanding consumer budgeting behavior. International Journal of Consumer Studies, 42, 448-459.

Xiao, J. J., \& O’Neill, B. (2018b). Propensity to plan, financial capability, and subjective financial wellbeing. International Journal of Consumer Studies, 42, 501-512.

Xie, Y., \& Hu, J. (2014). An introduction to the China Family Panel Studies (CFPS). Chinese Sociological Review, 47(1), 3-29.

Zimbardo, P. G., \& Boyd, J. N. (1999). Putting time in perspective: A valid, reliable individual-differences metric. Journal of Personality and Social Psychology, 77(6), 1271-1288. 
Table 1: Variable Specifications

\begin{tabular}{|c|c|}
\hline Variable Name & Question wording and coding \\
\hline \multicolumn{2}{|l|}{ Present bias } \\
\hline fw1911present_biased & $\begin{array}{l}\text { "I intend to live in the present more and do not consider the future. } \\
\text { 1. Totally inapplicable; } 2 \text {. Somewhat inapplicable; } 3 \text {. Generally } \\
\text { applicable; } 4 \text {. Somewhat applicable; } 5 \text {. Totally applicable; } 9 \text {. Don't } \\
\text { know." In the analyses, } 9 \text { was coded to } 1 \text {. Other values were } \\
\text { unchanged. }\end{array}$ \\
\hline \multicolumn{2}{|l|}{ Financial behavior } \\
\hline fw1901consider_cap & $\begin{array}{l}\text { The wording in the original question: "I will consider my capacity } \\
\text { when I go shopping. } 1 \text {. Totally inapplicable; } 2 \text {. Somewhat } \\
\text { inapplicable; 3. Generally applicable; } 4 \text {. Somewhat applicable; } 5 . \\
\text { Totally applicable; } 9 \text {. Don't know." In the analyses, } 9 \text { was coded to } \\
\text { 1. Other values were unchanged. }\end{array}$ \\
\hline fw1902pay_on_time & $\begin{array}{l}\text { "I pay my bills on time (such as water, gas, electricity, credit card, } \\
\text { etc.). } 1 \text {. Totally inapplicable; } 2 \text {. Somewhat inapplicable; } 3 \text {. Generally } \\
\text { applicable; } 4 \text {. Somewhat applicable; } 5 \text {. Totally applicable; } 9 \text {. Don't } \\
\text { know." In the analyses, } 9 \text { was coded to } 1 \text {. Other values were } \\
\text { unchanged. }\end{array}$ \\
\hline fw1903check_fin & $\begin{array}{l}\text { "I pay close attention to my financial situation (e.g., regular check } \\
\text { of bank account and financial balance). } 1 \text {. Totally inapplicable; } 2 . \\
\text { Somewhat inapplicable; } 3 \text {. Generally applicable; } 4 \text {. Somewhat } \\
\text { applicable; } 5 \text {. Totally applicable; } 9 \text {. Don't know." In the analyses, } 9 \\
\text { was coded to } 1 \text {. Other values were unchanged. }\end{array}$ \\
\hline fw1904plan & $\begin{array}{l}\text { "I make long-term financial plans. } 1 \text {. Totally inapplicable; } 2 . \\
\text { Somewhat inapplicable; } 3 \text {. Generally applicable; } 4 \text {. Somewhat } \\
\text { applicable; } 5 \text {. Totally applicable; } 9 \text {. Don't know." In the analyses, } 9 \\
\text { was coded to } 1 . \text { Other values were unchanged. }\end{array}$ \\
\hline fw1906underspend & $\begin{array}{l}\text { "In my daily life, I make ends meet and consume according to my } \\
\text { income. } 1 \text {. Totally inapplicable; } 2 \text {. Somewhat inapplicable; } 3 . \\
\text { Generally applicable; } 4 \text {. Somewhat applicable; } 5 \text {. Totally applicable; } \\
\text { 9. Don't know." In the analyses, } 9 \text { was coded to } 1 \text {. Other values } \\
\text { were unchanged. }\end{array}$ \\
\hline fw1907search_info & $\begin{array}{l}\text { "I will collect product information and compare various products } \\
\text { when I choose financial products. } 1 \text {. Totally inapplicable; } 2 \text {. } \\
\text { Somewhat inapplicable; } 3 \text {. Generally applicable; } 4 \text {. Somewhat } \\
\text { applicable; } 5 \text {. Totally applicable; } 9 \text {. Don't know." In the analyses, } 9 \\
\text { was coded to } 1 \text {. Other values were unchanged. }\end{array}$ \\
\hline fw1908have_debt & $\begin{array}{l}\text { "I will maintain financial balance using loans. } 1 \text {. Totally inapplicable; } \\
\text { 2. Somewhat inapplicable; } 3 \text {. Generally applicable; } 4 \text {. Somewhat } \\
\text { applicable; } 5 \text {. Totally applicable; } 9 \text {. Don't know." In the analyses, } 9 \\
\text { was coded to } 1 \text {. Other values were unchanged. }\end{array}$ \\
\hline fw1909bookkeep & $\begin{array}{l}\text { "I have the habit of bookkeeping, and record all the income and } \\
\text { expenditures. } 1 \text {. Totally inapplicable; } 2 \text {. Somewhat inapplicable; } 3 . \\
\text { Generally applicable; } 4 \text {. Somewhat applicable; } 5 \text {. Totally applicable; }\end{array}$ \\
\hline
\end{tabular}




\begin{tabular}{|c|c|}
\hline & $\begin{array}{l}\text { 9. Don't know." In the analyses, } 9 \text { was coded to } 1 . \text { Other values } \\
\text { were unchanged. }\end{array}$ \\
\hline fw1910spend_not_save & $\begin{array}{l}\text { "Spending money makes me more satisfied than saving money. } 1 . \\
\text { Totally inapplicable; } 2 \text {. Somewhat inapplicable; } 3 \text {. Generally } \\
\text { applicable; } 4 \text {. Somewhat applicable; } 5 \text {. Totally applicable; } 9 . \text { Don't } \\
\text { know." In the analyses, } 9 \text { was coded to } 1 \text {. Other values were } \\
\text { unchanged. }\end{array}$ \\
\hline fw1912spend_now & $\begin{array}{l}\text { "In my opinion, money is to be spent and we should spend it } \\
\text { whenever we have money. } 1 \text {. Totally inapplicable; } 2 \text {. Somewhat } \\
\text { inapplicable; } 3 \text {. Generally applicable; } 4 \text {. Somewhat applicable; } 5 . \\
\text { Totally applicable; } 9 \text {. Don't know." In the analyses, } 9 \text { was coded to } \\
\text { 1. Other values were unchanged. }\end{array}$ \\
\hline fw20borrow_more & $\begin{array}{l}\text { "Is your family willing to take more debts based on your current } \\
\text { financial situation? } 1 . \text { Very unwilling; } 2 \text {. Unwilling; 3. Fair; } 4 \text {. Willing; } \\
\text { 5. Very willing." }\end{array}$ \\
\hline fw241risk_attitude & $\begin{array}{l}\text { "If your family invest/In investment, what kind of risk are you } \\
\text { willing to take? } 1 . \text { High risk, high return; } 2 \text {. Moderate risk, steady } \\
\text { return; } 3 \text {. Low risk, low return; } 4 \text {. Unwilling to take any investment } \\
\text { risk." In the analyses, recoded as 1.25-unwilling to take any risk; } \\
2.5 \text {-low risk, low return; 3.75-moderate risk, steady return; 5-high } \\
\text { risk, high return. }\end{array}$ \\
\hline fw25ad_opp & $\begin{array}{l}\text { "If an advertisement claims that there is an investment project with } \\
\text { an annual return rate at } 50 \% \text {, would you invest in it? } \\
\text { 1. Yes; } 2 \text {. No; } 3 \text {. Will decide after learning more details of the } \\
\text { project" In the analyses, recoded as } 1 \text {-no; } 3 \text {-will decide after } \\
\text { learning more details of the project; } 5 \text {-yes. }\end{array}$ \\
\hline fw26friend_opp & $\begin{array}{l}\text { "If some close relatives/friends introduce you an investment } \\
\text { project with an annual return rate at } 50 \% \text {, would you invest in it? } 1 . \\
\text { Yes; } 2 \text {. No; } 3 \text {. Will decide after learning more details of the project." } \\
\text { In the analyses, recoded as } 1 \text {-no; } 3 \text {-will decide after learning more } \\
\text { details of the project; } 5 \text {-yes. }\end{array}$ \\
\hline fw9retire_cal & $\begin{array}{l}\text { "Whether you and your spouse have "calculated" the amount of } \\
\text { money to cover your elderly life cost? 1. Yes; } 5 . \text { No." In the analyses, } \\
\text { recoded as 1-no. 5-yes. }\end{array}$ \\
\hline \multicolumn{2}{|l|}{ Demographics } \\
\hline cfps_minzu_x & Ethnicity, 1-Han, 0-other \\
\hline cfps2014_age & Age, actual year \\
\hline cfps_gender & Gender, 1-male, 0-female \\
\hline qea0_married & Marital status, 1-married, 0-other \\
\hline p_income & Personal income, actual amount \\
\hline cfps2014edu_primary & Education, 1-primary school or lower, 0-other \\
\hline cfps2014edu_middle & Education, 1-middle school, 0-other \\
\hline cfps2014edu_high & Education, 1-high school, 0-other \\
\hline cfps2014edu_assiciate & Education, 1-three-year college, 0-other \\
\hline cfps2014edu_bachelor & Education, 1-bachelor degree or higher, 0-other \\
\hline
\end{tabular}


Table 2. Descriptive Statistics of the Variables $(N=3843)$

\begin{tabular}{|c|c|c|c|c|}
\hline & Minimum & Maximum & Mean & Std. Deviation \\
\hline \multicolumn{5}{|l|}{ Present Biased } \\
\hline Live in the present more & 1 & 5 & 2.77 & 1.36 \\
\hline \multicolumn{5}{|l|}{ Financial Behavior } \\
\hline $\begin{array}{c}\text { Take a high return ( } 50 \%) \text { investment } \\
\text { opportunity introduced by ads }\end{array}$ & 1 & 5 & 1.52 & 1.00 \\
\hline Willing to take more debts & 1 & 5 & 1.75 & 0.77 \\
\hline $\begin{array}{l}\text { Take a high return (50\%) investment } \\
\text { opportunity introduced by friends }\end{array}$ & 1 & 5 & 1.75 & 1.14 \\
\hline Maintain financial balance using loans & 1 & 5 & 1.78 & 1.18 \\
\hline Calculate retirement needs & 1 & 5 & 2.28 & 1.86 \\
\hline Have a habit of bookkeeping & 1 & 5 & 2.32 & 1.37 \\
\hline Spending is more satisfied than saving & 1 & 5 & 2.39 & 1.29 \\
\hline Willing to take financial risk & 1.25 & 5 & 2.44 & 1.19 \\
\hline $\begin{array}{l}\text { Money should be spent whenever we } \\
\text { have it }\end{array}$ & 1 & 5 & 2.57 & 1.31 \\
\hline Make long term financial plans & 1 & 5 & 2.84 & 1.31 \\
\hline Collect information and compare products & 1 & 5 & 2.86 & 1.52 \\
\hline $\begin{array}{l}\text { Pay close attention to own financial } \\
\text { situation }\end{array}$ & 1 & 5 & 3.69 & 1.26 \\
\hline Consider capacity when shopping & 1 & 5 & 4.03 & 1.04 \\
\hline Consume according to own income & 1 & 5 & 4.16 & 0.97 \\
\hline Pay bill on time & 1 & 5 & 4.37 & 0.99 \\
\hline \multicolumn{5}{|l|}{ Demographics } \\
\hline Han Ethnicity & 0 & 1 & 0.94 & 0.23 \\
\hline Age & 16 & 93 & 50.22 & 15.54 \\
\hline Male & 0 & 1 & 0.52 & 0.50 \\
\hline Married & 0 & 1 & 0.80 & 0.40 \\
\hline Personal income & 0 & 360000 & 14720.09 & 25718.28 \\
\hline Education: primary school or lower & 0 & 1 & 0.25 & 0.43 \\
\hline Education: middle school & 0 & 1 & 0.28 & 0.45 \\
\hline Education: high school & 0 & 1 & 0.25 & 0.43 \\
\hline Education: 3-year college & 0 & 1 & 0.11 & 0.32 \\
\hline Education: 4-year college or higher & 0 & 1 & 0.11 & 0.31 \\
\hline
\end{tabular}


Table 3. Exploratory Factor Analyses of Individual Financial Behaviors: Rotated Component Matrix

\begin{tabular}{lr|r|r|r|r} 
& \multicolumn{7}{c}{ Factors } \\
\cline { 2 - 7 } & Cautious & Managing & Naive & Impatient & Analytic \\
\hline Pay bills on time & .780 & .019 & .019 & .077 & -.005 \\
\hline Shop consider capability & .780 & .013 & -.017 & -.029 & -.008 \\
\hline Underspend & .723 & .094 & -.034 & -.025 & .084 \\
\hline Make long term goals & .153 & .709 & .063 & -.073 & .140 \\
\hline Book keeping & -.014 & .636 & .002 & -.004 & -.053 \\
\hline Search for information & .138 & .591 & .242 & .029 & .055 \\
\hline Check finances & .499 & .508 & .034 & -.051 & .069 \\
\hline Have debts & -.157 & .466 & -.020 & .234 & -.235 \\
\hline Take 50\% return & -.023 & .032 & .866 & -.006 & .032 \\
\hline $\begin{array}{l}\text { investment opportunity } \\
\text { introduced by friends }\end{array}$ & & & & & \\
\hline Take 50\% return & -.029 & .018 & .838 & .008 & .055 \\
\hline $\begin{array}{l}\text { investment opportunity } \\
\text { introduced by friends }\end{array}$ & & & & & \\
\hline Willing to take high risk & .028 & .277 & .529 & .001 & -.268 \\
\hline Prefer spending now & .016 & -.119 & -.043 & .821 & -.025 \\
\hline Prefer for spending & .010 & .134 & .045 & .800 & .009 \\
\hline Calculate retirement & -.097 & .258 & .040 & .138 & .763 \\
\hline needs & & & & & \\
\hline Willing to borrow more & -.208 & .226 & .097 & .183 & -.566 \\
\hline Extraction & & & & & \\
\hline
\end{tabular}

Extraction Method: Principal Component Analysis.

Rotation Method: Varimax with Kaiser Normalization.

a. Rotation converged in 6 iterations. 
Table 4. OLS Regression Results on Cautious Behavior

\begin{tabular}{|l|c|c|c|}
\hline & \multicolumn{3}{|c|}{ Model 3 } \\
\hline & $\mathrm{B}$ & Beta & $\mathrm{p}$ \\
\hline Present bias & -0.352 & $-0.609^{*}$ & 0.000 \\
\hline Present bias squared & 0.068 & $0.700^{*}$ & 0.000 \\
\hline Ethnicity-Han & 0.057 & 0.017 & 0.304 \\
\hline Age & -0.001 & -0.013 & 0.459 \\
\hline Male & -0.064 & $-0.040^{*}$ & 0.012 \\
\hline Married & 0.120 & $0.061^{*}$ & 0.000 \\
\hline Personal income & $5.544 \mathrm{E}-07$ & 0.018 & 0.307 \\
\hline Edu-middle school & 0.073 & $0.042^{*}$ & 0.037 \\
\hline Edu-high school & 0.107 & $0.059^{*}$ & 0.004 \\
\hline Edu-associate degree & 0.197 & $0.079^{*}$ & 0.000 \\
\hline Edu-bachelor or more & 0.124 & $0.048^{*}$ & 0.012 \\
\hline $\mathrm{p}$ of overall model & .000 & & \\
\hline $\mathrm{R}^{2}$ change & .012 & & \\
\hline $\mathrm{p}$ of R ${ }^{2}$ change & .000 & & \\
\hline
\end{tabular}

Note: "Edu-primary school or lower" is used as a reference category. 
Table 5 OLS Regression Results on Managing Behavior

\begin{tabular}{|l|c|c|c|}
\hline & \multicolumn{3}{|c|}{ Model 3 } \\
\hline & $\mathrm{B}$ & Beta & $\mathrm{p}$ \\
\hline Present bias & -0.051 & -0.075 & 0.329 \\
\hline Present bias squared & 0.001 & 0.007 & 0.924 \\
\hline Ethnicity-Han & 0.021 & 0.005 & 0.746 \\
\hline Age & -0.008 & $-0.130^{*}$ & 0.000 \\
\hline Male & -0.002 & -0.001 & 0.935 \\
\hline Married & 0.132 & $0.057^{*}$ & 0.000 \\
\hline Personal income & $1.379 \mathrm{E}-06$ & $0.038^{*}$ & 0.029 \\
\hline Edu-middle school & 0.159 & $0.077^{*}$ & 0.000 \\
\hline Edu-high school & 0.238 & $0.111^{*}$ & 0.000 \\
\hline Edu-associate degree & 0.327 & $0.112^{*}$ & 0.000 \\
\hline Edu-bachelor or more & 0.215 & $0.071^{*}$ & 0.000 \\
\hline $\mathrm{p}$ of overall model & .000 & & \\
\hline $\mathrm{R}^{2}$ change & .050 & & \\
\hline $\mathrm{p}$ of $\mathrm{R}^{2}$ change & .000 & & \\
\hline
\end{tabular}


Table 6 OLS Regression Results on Impatient Behavior

\begin{tabular}{|l|c|c|c|}
\hline & \multicolumn{3}{|c|}{ Model 3 } \\
\hline & $\mathrm{B}$ & Beta & $\mathrm{p}$ \\
\hline Present bias & 0.583 & $0.737^{*}$ & 0.000 \\
\hline Present bias squared & -0.039 & $-0.296^{*}$ & 0.000 \\
\hline Ethnicity-Han & -0.020 & -0.004 & 0.778 \\
\hline Age & -0.001 & -0.014 & 0.396 \\
\hline Male & 0.018 & 0.008 & 0.570 \\
\hline Married & 0.007 & 0.003 & 0.850 \\
\hline Personal income & $8.023 \mathrm{E}-07$ & 0.019 & 0.234 \\
\hline Edu-middle school & -0.080 & -0.034 & 0.066 \\
\hline Edu-high school & 0.009 & 0.003 & 0.852 \\
\hline Edu-associate degree & -0.006 & -0.002 & 0.918 \\
\hline Edu-bachelor or more & 0.040 & 0.012 & 0.509 \\
\hline $\mathrm{p}$ of overall model & .000 & & \\
\hline $\mathrm{R}^{2}$ change & .003 & & \\
\hline $\mathrm{p}$ of $\mathrm{R}^{2}$ change & .167 & & \\
\hline
\end{tabular}


Table 7 OLS Regression Results on Naïve Behavior

\begin{tabular}{|l|c|c|c|}
\hline & \multicolumn{3}{|c|}{ Model 3 } \\
\hline & B & Beta & $p$ \\
\hline Present bias & 0.097 & 0.138 & 0.067 \\
\hline Present bias squared & -0.023 & $-0.196^{*}$ & 0.010 \\
\hline Ethnicity-Han & -0.207 & $-0.050^{*}$ & 0.002 \\
\hline Age & -0.018 & $-0.292^{*}$ & 0.000 \\
\hline Male & 0.054 & 0.028 & 0.071 \\
\hline Married & -0.062 & -0.026 & 0.090 \\
\hline Personal income & $-6.255 \mathrm{E}-07$ & -0.017 & 0.325 \\
\hline Edu-middle school & -0.084 & $-0.039 *$ & 0.043 \\
\hline Edu-high school & -0.046 & -0.021 & 0.289 \\
\hline Edu-associate degree & -0.082 & -0.027 & 0.140 \\
\hline Edu-bachelor or more & -0.052 & -0.017 & 0.363 \\
\hline$p$ of overall model & .000 & & \\
\hline$R^{2}$ change & .085 & & \\
\hline$p$ of $R^{2}$ change & .000 & & \\
\hline
\end{tabular}


Table 8. OLS Regression Results on Analytic Behavior

\begin{tabular}{|l|c|c|c|}
\hline & \multicolumn{3}{|c|}{ Model 3 } \\
\hline & $\mathrm{B}$ & Beta & $\mathrm{p}$ \\
\hline Present bias & -0.236 & $-0.316^{*}$ & 0.000 \\
\hline Present bias squared & 0.034 & $0.272^{*}$ & 0.001 \\
\hline Ethnicity-Han & 0.265 & $0.061^{*}$ & 0.000 \\
\hline Age & 0.003 & $0.042^{*}$ & 0.023 \\
\hline Male & -0.052 & -0.026 & 0.118 \\
\hline Married & 0.039 & 0.016 & 0.334 \\
\hline Personal income & $1.189 \mathrm{E}-07$ & 0.003 & 0.866 \\
\hline Edu-middle school & 0.063 & 0.028 & 0.169 \\
\hline Edu-high school & 0.038 & 0.016 & 0.426 \\
\hline Edu-associate degree & 0.028 & 0.009 & 0.653 \\
\hline Edu-bachelor or more & -0.098 & -0.030 & 0.123 \\
\hline$p$ of overall model & .000 & & \\
\hline$R^{2}$ change & .010 & & \\
\hline$p$ of $R^{2}$ change & .000 & & \\
\hline
\end{tabular}


Figure 1. Line Charts of Financial Behavior by Present Bias Status

1.1. Cautious Behavior

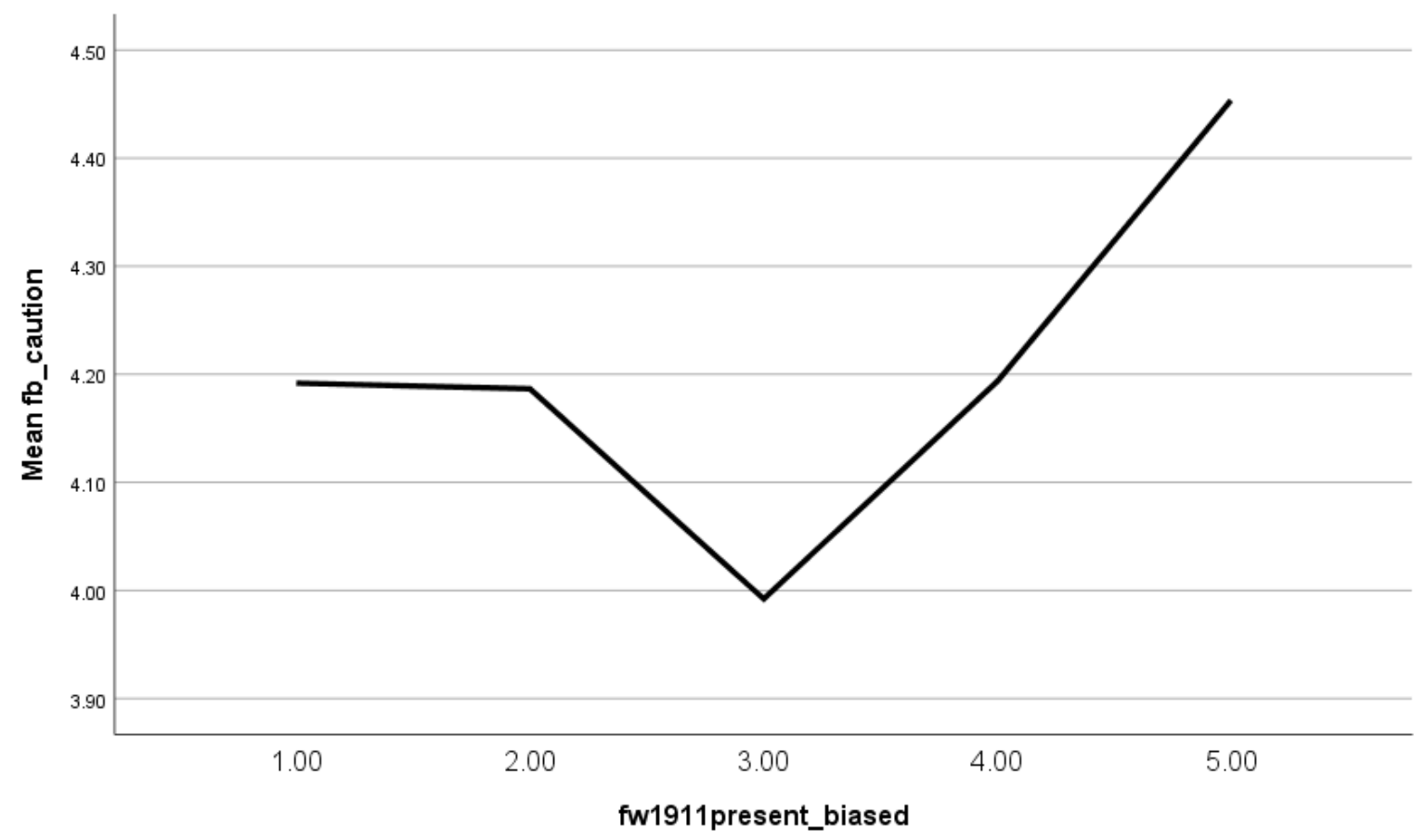

1.2. Managing Behavior

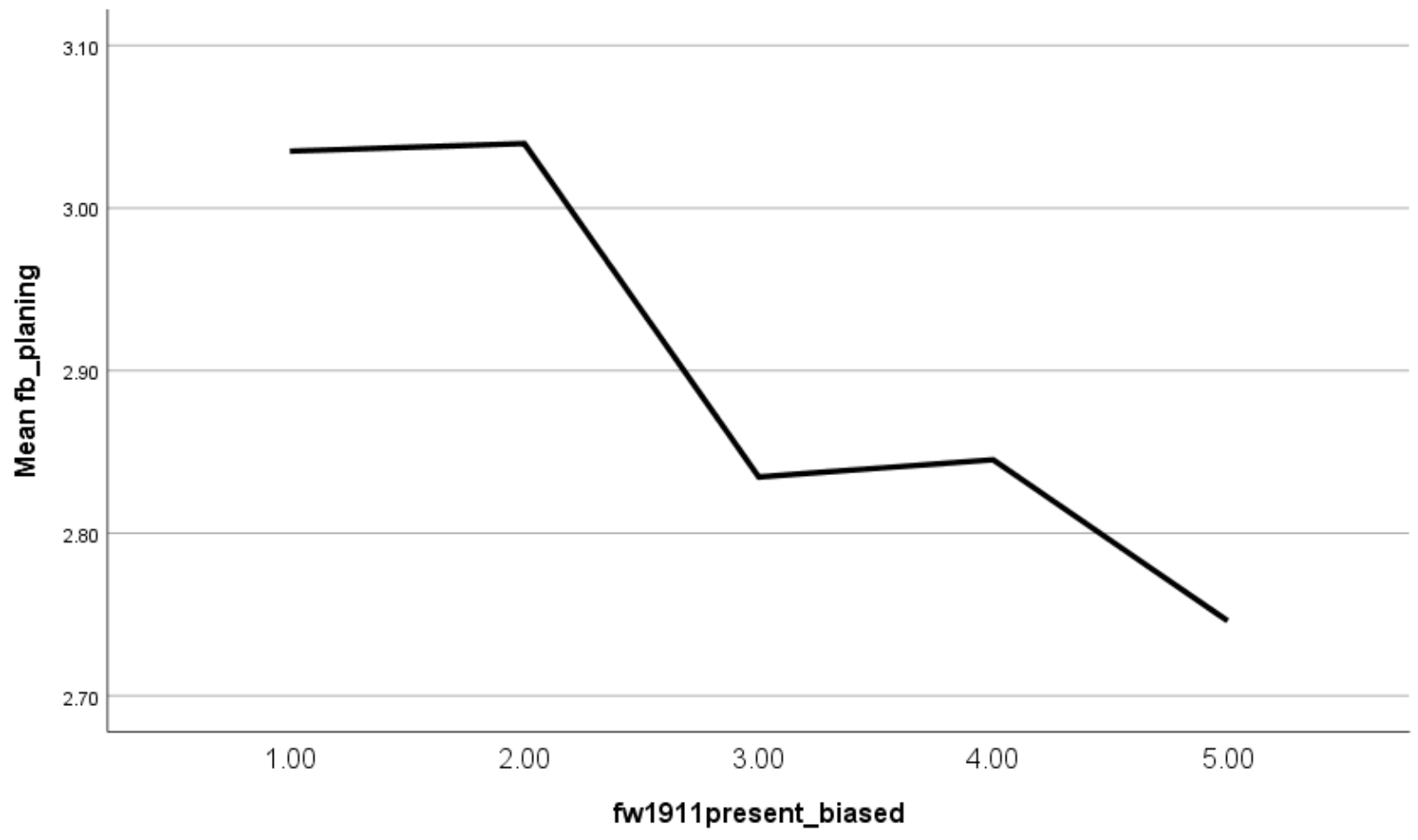




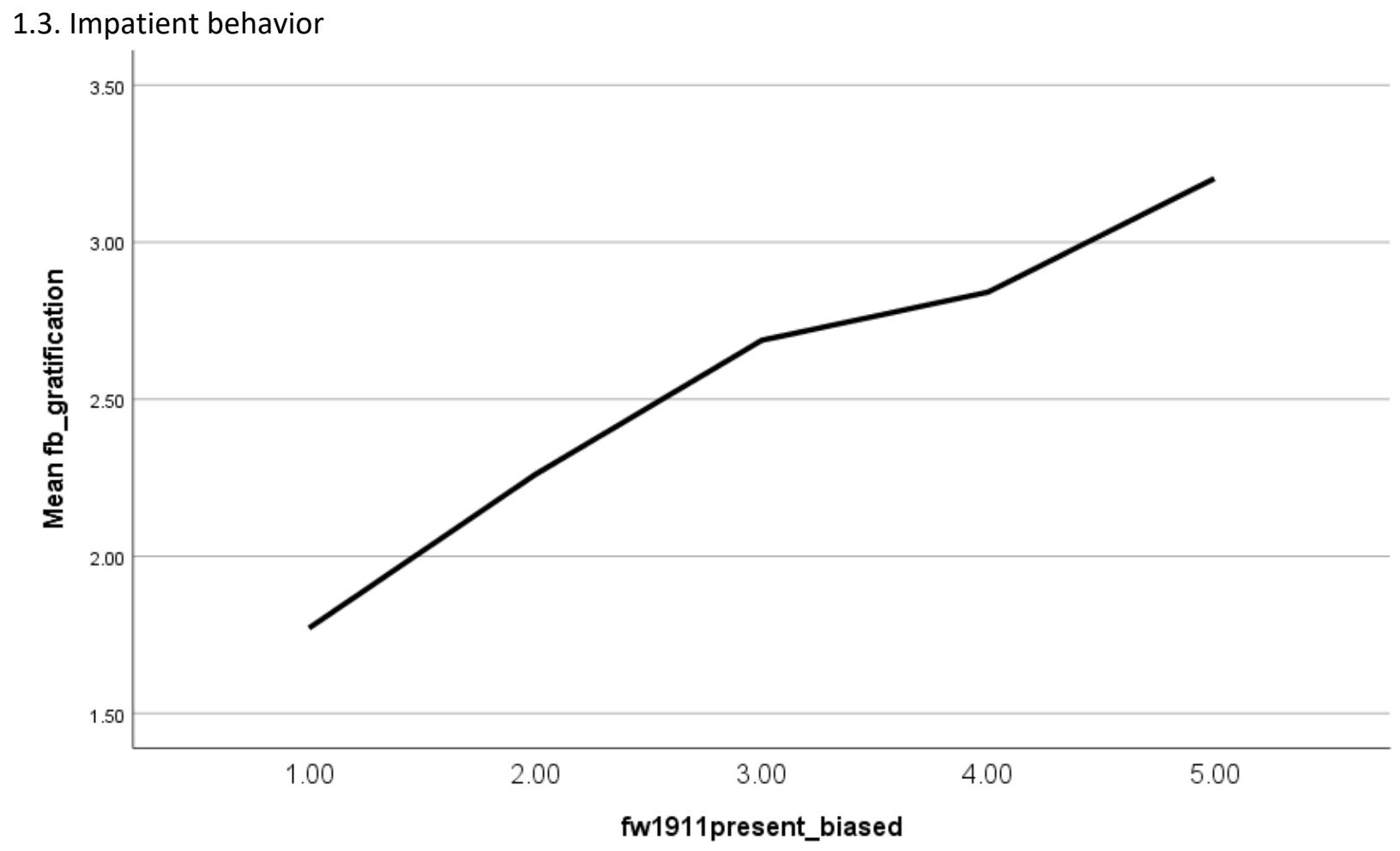

1.4. Naïve Behavior

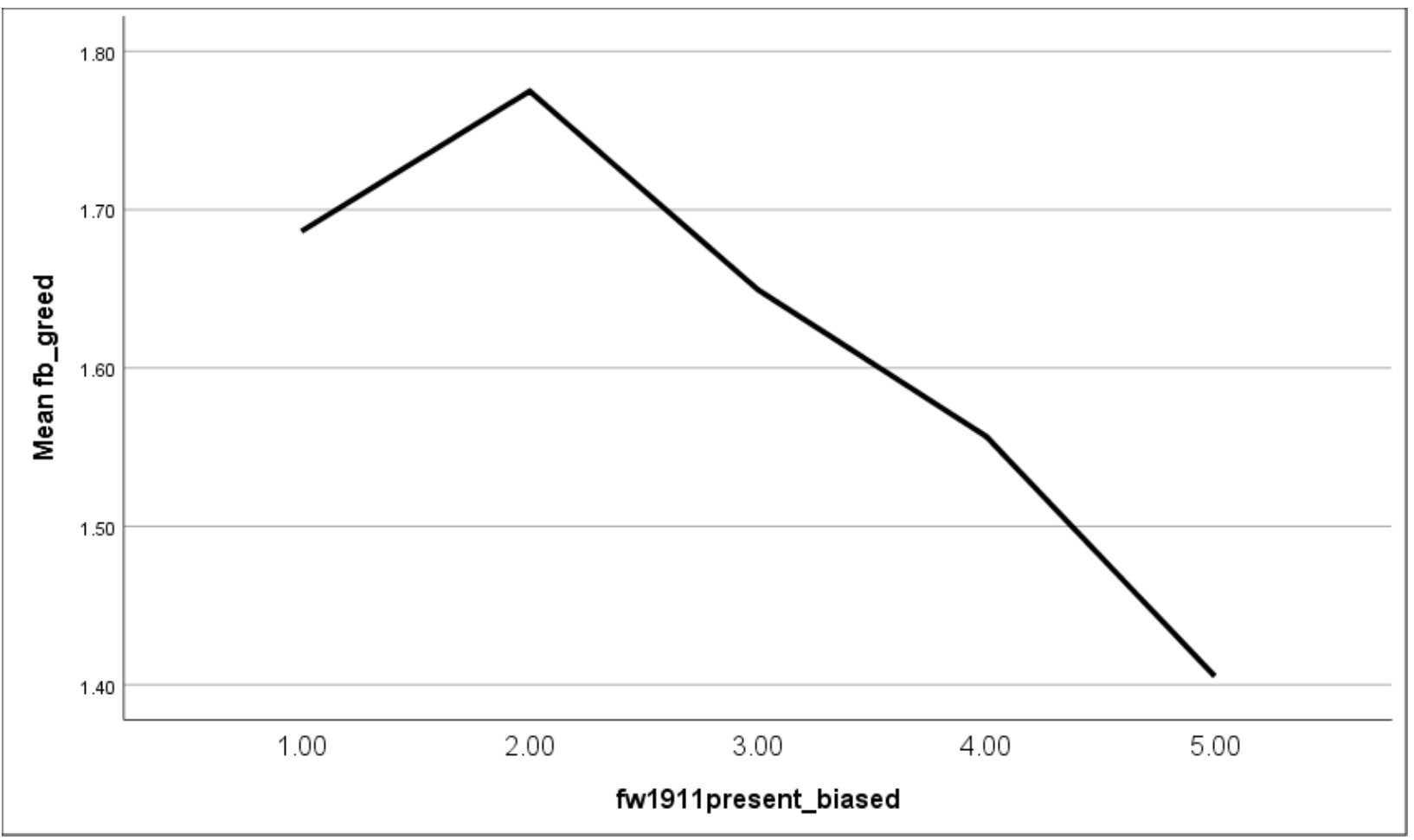


1.5. Analytic Behavior

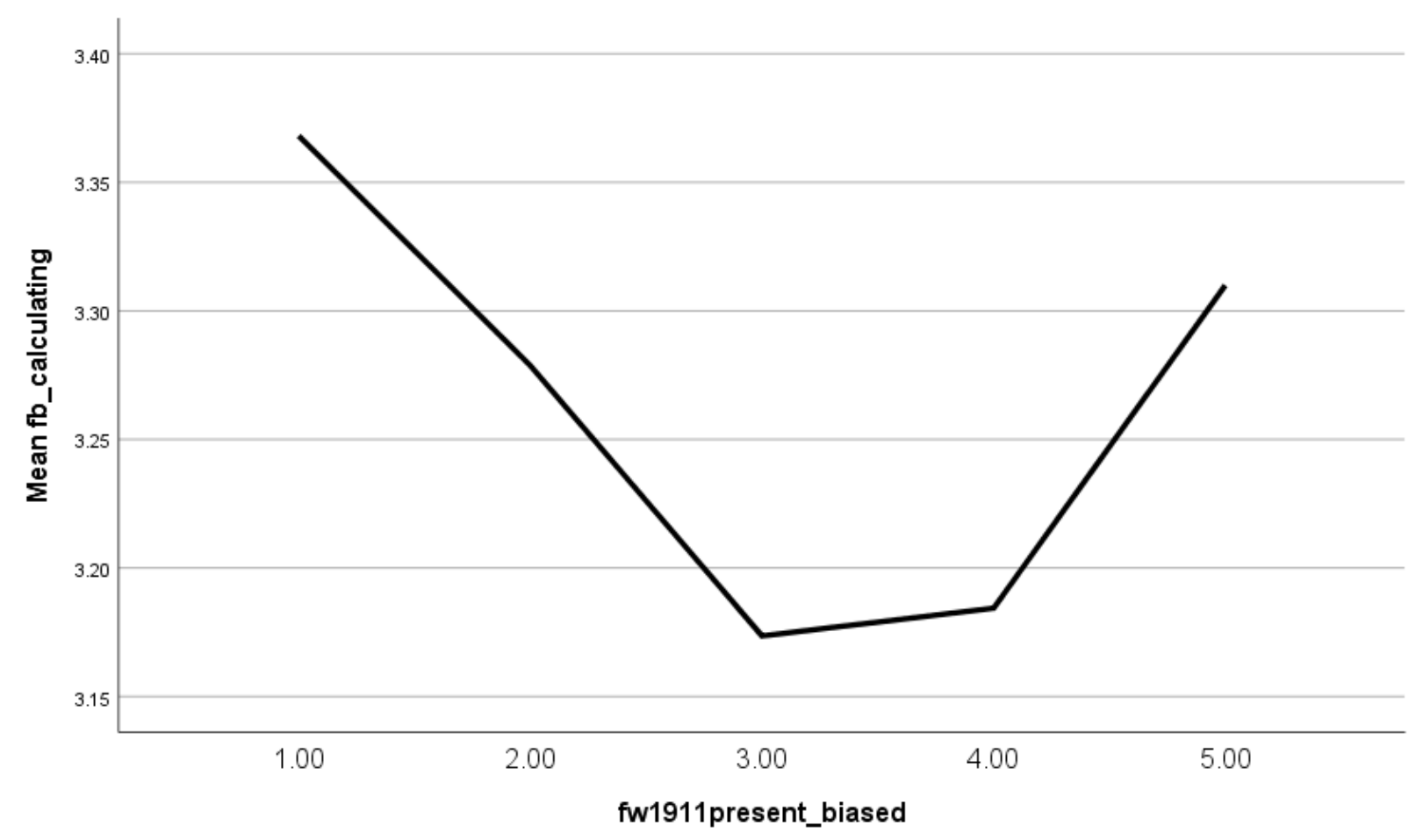

